Pegem Journal of Education \& Instruction, 3(4), 2013, 83-96

Pegem Eğitim ve Öğretim Dergisi, 3(4), 2013, 83-96

www.pegegog.net

LISE ÖĞRENCILERININ ÖĞRENME STiLLERININ ELEŞTiREL DÜŞÜNME EĞiLIMLERINI YORDAMA DÜZEYi

\title{
THE PREDICTION LEVEL OF HIGH SCHOOL STUDENTS' LEARNING STYLES ON CRITICAL THINKING DISPOSITIONS
}

\author{
Cemil YÜCEL ${ }^{\mathrm{a}^{*}}$, Ufuk ULUÇINAR ${ }^{\mathrm{b}}$ \\ ${ }^{a}$ Eskişehir Osmangazi Üniversitesi Eğitim Fakültesi, Eskişehir/Türkiye \\ ${ }^{b}$ Uşak Üniversitesi Eğitim Fakültesi, Uşak/Türkiye
}

Öz

$\mathrm{Bu}$ araştırmanın amacı, lise öğrencilerinin öğrenme stillerinin eleştirel düşünme eğilimlerini yordayıcı etkisinin olup olmadığını incelemektir. Bu amaçla lise öğrencilerinin öğrenme stillerinin eleştirel düşünme eğilimlerini ne oranda açıkladığının belirlenmesi hedeflenmektedir. Araştırmanın örneklemini, Uşak ilinde orta öğretim kurumlarından tesadüfi örnekleme yöntemi ile üç liseden seçilen 271 öğrenci oluşturmaktadır. Araştırmanın verileri, araştırmacılar tarafından geliştirilen Eleştirel Düşünme Eğilimleri Ölçeği ve Grasha-Reichmann tarafından geliştirilen ve Koçak (2007) tarafından Türkçeye uyarlanan Öğrenme Stilleri Ölçeği ile toplanmıştır. Elde edilen bulgulara göre, lise öğrencilerinin öğrenme stillerinden sistemli çalışma eğilimi, öğretmene bağımlıık ve sınıf içi işbirliği stillerinin nedensellik, meraklılık ve açık fikirlilik eğilimlerini anlamlı bir şekilde yordadığı, rekabetçi öğrenme stilinin eleştirel düşünme eğilimlerinin hiç birisini yordamadığı tespit edilmiştir.

Anahtar Kelimeler: Lise öğrencileri, öğrenme stilleri, eleştirel düşünme eğilimleri.

\begin{abstract}
The purpose of this study is to investigate whether there is a predictive effect of learning styles on critical thinking dispositions of high school students. Thus, it aims to determine how much of learning styles used by high school students depending on the nature of learning settings explain the variance in critical thinking dispositions. The sample of the study is composed of 271 high school students chosen randomly from three high schools. The data was collected using Critical Thinking Dispositions Scale developed by reseachers and Learning Styles Scale developed by Reichmann-Grasha and adapted into Turkish language by Koçak (2007). The findings indicated that while high school students learning styles (systematically study, dependence on teachers and cooperation in classroom) predict significantly causal thinking, courisity and openmindedness dispositions, competitive learning style does not predict significantly the critical thinking dispositions.
\end{abstract}

Key Words: High school students, learning styles, critical thinking dispositions.

Giriş

Öğrenme oldukça karmaşık bir olgu olup bilgi, beceri, strateji, inanç, tutum ve davranışların edinimini ve değiştirilmesini kapsar (Schunk, 2009). Bu olgu, öğrenmenin kökenlerindeki psikolojik (yapısalcılık ve işlevselcilik) ve felsefi temellere (akılcılık ve deneycilik) dayanılarak çeşitli öğrenme teorilerine göre

\footnotetext{
*Yazar: cemilyucel@gmail.com
} 
açıklanmıştır. Bunlardan davranışçı (deneyci) teoriler, öğrenmeyi, bireyin uyarıya verdiği tepki bağlamında bireyde gözlemlenen ve ölçülebilen davranışlar olarak tanımlarken, bilişsel teoriler (işlevsel) öğrenmede bilginin hangi yollarla kazanıldığını, bellekte nasıl düzenlendiğini ve nasıl depolandığını zihinsel kavramlarla açıklamaktadır (Schunk, 2009; Taylor ve MacKenney, 2008). Vygotsky'nin sosyokültürel teorisinde öğrenmede sosyal etkileşimin rolüne dikkat çekilirken, benzer şekilde Bandura'nın sosyobilişsel teorisinde bireyin öğrenmelerinin ve davranışlarının çevrenin birey üzerindeki rol model etkisi ile gerçekleştiğine dikkat çekmektedir. Bu açıdan bakıldığında sosyo bilişsel teori; davranış̧̧ı teoriler ile bilişsel teoriler arasında bir köprü vazifesi görmektedir. Bu yüzden öğrenme, kişinin hem kendisinin bilgiyi yapılandırmasını hem de onun çevre ile edinilmesini kapsamaktadır.

Eğitim programlarının temel felsefesi ve psikolojik alt yapısında bu öğrenme teorilerinin varsayımları yatmaktadır. Ülkemizde 2005 yılında uygulamaya konulan eğitim programlarının temel felsefesinde yapılandırmacılık olarak da bilinen yaklaşımda yukarıda belirtilen bilişsel (Piaget), sosyo-bilişsel (Bandura), sosyo-kültürel (Vygotsky) teorilerin etkileri görülmektedir. Bu yaklaşıma göre, Bruner öğrenme teorisinde de ifade ettiği gibi, öğrenciler aktif olarak çevreleri ile etkileşime girer, önceki ve mevcut bilgilerine dayalı olarak öğrenmelerini yapılandırırlar. Öğrenciler bu süreçte bilgiyi seçip onu farklı şekillerde Piaget'in bilişsel gelişim kuramında ifade ettiği zihinsel şemalara göre anlamlandırırlar, varsayımlarını ve kararlarını bu şemalar üzerine kurarlar. Bruner'in öğrenme teorisinde amaç, yapılandırmacılığın da özünde olduğu gibi öğrencilerin kendi kendilerine keşfederek öğrenmelerini sağlamaktır. Bu durum, öğretmen ve öğrencilerin aktif bir öğrenme ortamında birlikte yer almasını gerektirir (Prithchard ve Woolard, 2010). Bu açıdan öğretmenin bu süreçte öğrencilerin öğrenmelerinde mediatör (aracı) etkiye sahip olması nedeniyle öğretmenlerin öğrenme teorilerinin fakında olması faydalı olabilir. Bu teoriler aynı zamanda öğretmenlere, öğrencilerin hangi biçimlerde öğrendiklerine ilişkin perspektif kazandırması açısından önemli görülmektedir. Bu sayede, öğretmenler sınıf içerisinde öğrencilerin öğrenme stillerine uygun olarak öğretim sergileyebilirler. Diğer yandan, öğretmenlerin özellikle özel zorluğu ve eğitim ihtiyacı olan öğrencilerin öğrenmelerini nasıl kolaylaştırabileceklerini bilmeleri önemli bir husus olarak söylenebilir. Buna bağlı olarak bu süreçlerde öğrenme stilleri öğrencilerin öğrenme potansiyellerini artırmada etkili öğrenme yolları sunduğu ifade edilmektedir (Reid, 2005).

\section{Öğrenme Stilleri}

Öğrenme stilleri öğrencilerin öğrenmelerinde bir etken olarak görülmektedir. Öğrencilerin sahip olduğu baskın öğrenme stili, öğrencinin bireysel farklılığına göre bilgiyi en iyi şekilde alma, işleme ve yorumlama şeklini ifade etmektedir (Berry ve Settle, 2011). Tuan (2011)'a göre öğrenme stili öğrencinin nasıl öğrendiği ve nasıl öğrenmeyi sevdiğinin göstergesidir. Öğrenme stilleri hakkında öne sürülen teorilerde de daha çok öğrencilerin bilgiyi işleme biçimlerindeki farklılıklardan dolayı, bu teoriler öğrenme stillerini farklı bağlam ve perspektifte anlama üzerine kuruludur (Kozub, 2010; Kuhn, 2009; McGlone, 2011; Rafael ve Francisco, 2011; Scott, 2010; Sinclaire, 2012; Zacharis, 2010; Zacharis, 2011; Zhou, 2011). Kolb, Piaget'in özümseme ve uyum sağlama kavramlarına dayandırarak öğrenme stillerini ayrıştırıcı, özümseyici, dönüştürücü ve yerleştirici; Myers-Briggs öğrenme stillerini Jung'ın geliştirdiği kişilik tipleri teorisine dayalı olarak dışa dönük, duyusal, düşünen, algılayan ve içe dönük, sezgici, hisseden, yargılayan; Hunney ve Mummord, aktivist, yansıtıcı, teorisyen, yararcl; Grasha-Reichmann, bağımlı, işbirlikçi ve bağımsız öğrenme stilleri şeklinde ele almıştır. Diğer yandan, Dunn ve Dunn ise, diğerlerinden farklı olarak öğrenme stillerinde çevresel (ses, ışık, sıcaklık, tasarım), duyuşsal (motivasyon, sorumluluk, uyma, ısrar), sosyolojik (bağımsız, ikili gruplar, akran, otorite öğrenme), fizyolojik (algısal, nefes alma, zaman, hareketlilik) ve bilişsel (global/analitik) faktörlerin etkisine vurgu yapmıştır (Dunn, 2000; Pritchard, 2009; Reid, 2005; Sims ve Sims, 1995). Bu yüzden öğrencilerin başarılı olmaları için öğretimin onların öğrenme tercihleri ile ilişkilendirilmesi gerekir (Koçakoğlu, 2010; Kuhn, 2009). Buna göre eğitim programı esnek olmalı, farklı etkinliklerle durum analizleri, rol oynama, takım projeleri, oyunlar, simülasyon eğitimi gibi öğrenme aktiviteleri öğrenme-öğretme sürecine dahil edilmelidir (Gantasala ve Gantasala, 2009). Berry ve Settle'a (2011) göre öğrenme stilleri öğrencinin eğitim 
yaşantılarından etkilenebilir. Örneğin, anlama tercihi olan öğrenciye içeriği zengin olan bir ders sayesinde sezgisel beceriler öğretilebilir. Bu şekilde öğrenme stilleri materyale ulaşma, etkinlik tasarlama, öğretmenlerin öğretim seçenekleri, performans değerlendirmeleri üzerine etkiye sahiptir. Eğitimciler analiz, akıl yürütme ve problem çözme becerilerinin yanı sıra sezgi, hissetme, anlamlandırma, hayal kurmanın üzerine vurgu yapmalıdır. Bu nedenle öğretim yöntemleri, yaşantı, düşünme, kavramsallaştırma ile birlikte tüm öğrenme stilleri dikkate alarak tasarlanması ön görülmektedir (Zacharis, 2011).

Öğrenme aktiviteleri öğrenme stillerine mümkün olduğunca en uygun şekilde seçilmelidir. Böylece en etkili öğrenme gerçekleşir (Agarwal ve Jaiswal, 2010). Öğrencilere sahip olmadıkları öğrenme stilleri kazandırılmalıdır. Nitekim Tulbure'ın çalışmasına göre dönüştürücü öğrenme stiline sahip olan üç farklı fakültede öğrenim gören öğrencilere işbirlikçi öğrenme, araştırma ve problem çözme stillerini kullanma öğretildiğinde akademik başarılarının arttığı görülmüştür (Tulbure, 2009). Bu nedenle öğrencilerin öğrenme süreçlerine aktif bir şekilde katılımları sağlanmalıdır. Öğrenme stili, bireylerin tercihine bağlı olarak bilgi en iyi şekilde öğrenme yolu olarak tanımlandığından, kişinin başarısını doğrudan etkileyebileceği söylenebilir. Her ne kadar Meera, Steven, Ronald ve Alen (2009), öğrenme stillerinin akademik başarının \%3'ünü açıkladığını belirtseler de alan yazındaki bir çok çalışma öğrencilerin öğrenme stillerinin öğrenci başarısına çok daha fazla tesir ettiğini göstermektedir (Ahmad, Jelas ve Ali, 2011; Rogers ve McNeill, 2009; Terregrossa, Englander ve Wang, 2010; Zhou, 2011).

\section{Eleştirel Düşünme}

Eleştirel düşünme nedenlere ve gerekçelere bağılı olarak bir kritere göre düşünme biçimidir (Lipman, 1988). Hooglund (1993)'a göre eleştirel düşünme, yansıtıcı olarak dikkatli düşünme biçimi olarak ifade edilir. Bu dikkatli düşünme biçimi, bireylerin kendi eylemlerini ve adımlarını yönlendirirken, onları değerlendirme yapmaya olanak tanır. Dolayısıyla eleştirel düşünce, öğrencilerin günlük düşünce yapıları, kişisel karar ve eylemlerinin temelinde yatan varsayımlarını incelemelerine fırsat tanır (Hawkins, 2006). Bu yüzden eğitim programlarında öğrencilerin eleştirel düşünme, karar verme ve etkili değerlendirme yapma yeteneklerini geliştirme amaçlanır (Govier, 1989; Mcmillan, 1987; Smith, 2003).

Öğrencilerimize uygun kavram, standart, strateji ve ilkeleri kullanmalarını sağlama, eleştirel düşünme becerilerinin kazandırılmasında etkili bir öğretim biçimidir (Bailin, Case, Coombs ve Daniels, 1999). Schafersman'a (1991) göre, eleştirel düşünme öğretimi aktif bir süreci gerektirir. Bu nedenle analiz, sentez ve değerlendirme gibi entelektüel beceriler sınıf içerisinde uygulamalı etkinliklerle öğretilmelidir. Uygulanan öğretim etkinlikleri öğrencilerin eleştirel düşünme becerilerini gelişmesine yardım etmekte olup öğretmenlerin de bu gelişimi gerçekleştirmesi için sınıf aktivitelerini yakından takip etmeleri gerekir (Duron, Limbach ve Waugh, 2006). Bu bağlamda öğretmenler öğrencilerine sınıf içerisindeki etkinliklerde grup tartışmaları, bağımsız çalışma, sunum yapma, yazılı sınav yapma, yazma aktivitelerini gerçekleştirdiklerinde eleştirel düşünme becerilerinin gelişmesi de sağlanabilir (Baum ve Neubill, 2010; Tsui,1999).

$\mathrm{Bu}$ durumdan hareketle, öğrencilerin eleştirel düşünme becerilerinin gelişmesi öğretmenin sınıf içerisinde öğrencilerin öğrenme stiline uygun öğrenme yaklaşımlarının kullanıldığı ve öğrencilerin sınıf içerisinde zihinsel olarak aktif olduğu bir öğrenme ortamı ile mümkün görünmektedir. Öğrenme aktiviteleri öğrenme stillerine mümkün olduğunca en uygun şekilde seçilmelidir. Böylece en etkili öğrenme gerçekleştiği söylenebilir (Agarwal ve Jaiswal, 2010). Dolayısıyla öğrenme stillerine uygun öğrenme yaklaşımlarının (işbirlikçi öğrenme, proje tabanlı öğretim, problem çözme vb.) kullanıldığı etkinliklerde öğrencilerin eleştirel düşünme becerileri gelişmektedir (Richardson ve Ice, 2010). Uygun öğrenme stilinin öğrencilerin eleştirel düşünme eğilimlerini artırmada etkisinin olabileceği düşünülmektedir. Bu durumdan hareketle araştırmada lise öğrencilerinin öğrenme stillerinin eleştirel düşünme eğilimlerini yordama durumu araştırılmıştır. Araştırmada öğrenme stilleri bağımsız değişken olup, eleştirel düşünme eğilimleri bağımlı değişken olarak ele alınmıştır. 


\section{Yöntem}

\section{Araştırma Modeli}

Lise öğrencilerinin öğrenme stilleri ile eleştirel düşünme eğilimleri arasındaki ilişkiyi ortaya koymayı amaçlayan bu araştırma, ilişkisel modelde desenlenmiştir. iliş̧kisel modelde desenlenen araştırmalar, iki ya da daha fazla değişken arasındaki ilişkileri belirlemek ve neden-sonuç ile ilgili ipuçları elde etmek amacıyla yapılır (Büyüköztürk, Kılıç-Çakmak, Akgün, Karadeniz ve Demirel, 2009). Araştırmada öğrenme stillerinin sistematik çalışma, öğretmene bağımlılık, iş birliği, rekabetçi boyutları ile eleştirel düşünme eğilimlerinin nedensel düşünme, açık fikirlilik ve meraklılık boyutları arasındaki ilişkiler tespit edilmeye çalışılmıştır.

\section{Evren ve Örneklem}

Araştırmanın evrenini, 2012-2013 eğitim-öğretim yılında Uşak merkez ilindeki ortaöğretim kurumlarında öğrenim gören lise öğrencileri oluşturmaktadır. Örneklemini ise, merkez okullardan tesadüfi örnekleme yoluyla 3 okuldan seçilen 271 öğrenci oluşturmaktadır. Örneklem grubuna ilişkin demografik bilgiler, Tablo 1'de sunulmuştur.

Tablo 1

Örneklem Grubunun Demografik Bilgilerine Ait Frekans ve Yüzde Dağılımları.

\begin{tabular}{|c|c|c|}
\hline Cinsiyet & $\mathrm{N}$ & $\%$ \\
\hline Kız & 177 & 65,3 \\
\hline Erkek & 94 & 34,7 \\
\hline \multicolumn{3}{|l|}{ Alan } \\
\hline Alan yok & 83 & 30,6 \\
\hline Sözel & 32 & 11,8 \\
\hline Eşit ağırlık & 96 & 35,4 \\
\hline Sayısal & 52 & 19,2 \\
\hline \multicolumn{3}{|l|}{ Sınıf düzeyi } \\
\hline 1. & 84 & 31,0 \\
\hline 2. & 78 & 28,8 \\
\hline 3. & 59 & 21,8 \\
\hline 4. & 50 & 18,5 \\
\hline Toplam & 271 & 100 \\
\hline
\end{tabular}

Tablo 1'de görüldüğü gibi örneklem grubuna 177 kız (\% 65,3), 94 erkek (\% 34,7) öğrenci katılmıştır. Örneklemde yer alan öğrencilerin 83'ünün alanı yok (\% 30,6), 32'si sözel (\%11,8), 96'sı eşit ağırlık (\% $35,4)$ ve 52 'si sayısal $(\% 19,2)$ alan türündedir. Öğrencilerin $84^{\prime}$ ü 9 . Sınıf (\% 31,0), 78'i 10. Sınıf $(\% 28,8)$, 59’u 11. Sınıf (\% 21,8) ve 50'si 12 . Sınıf (\% 18,5) düzeyindedirler.

\section{Veri Toplama Araçları}

Araştırmada, eleştirel düşünme eğilimleri ölçeği ve öğrenme stilleri ölçeği kullanılmış olup, ölçeklere ilişkin bilgiler aşağıda yer almaktadır.

\section{Eleştirel düşünme eğilimleri ölçeği}

Araştırmacılar tarafından geliştirilen Eleştirel Düşünme Eğilimleri Ölçeği, başlangıç aşamasında literatürde yer alan eleştirel düşünme eğilimi boyutları belirlenerek eleştirel düşünmede en çok vurgulanan ve önemli olduğu düşünülen, Sorgulama (Ennis, 1996; Perkins, Jay ve Tishman, 1993; Siegel, 1988), Açık Fikirlilik (Chen, Cheng, Liu ve Tsai, 2011; Ennis, 1996; Facione, Facione ve Sanchez, 1994; Irani, Rudd, Gallo, Ricketts, Friedel ve Rhoades, 2007; Park ve Kwon, 2007), Meraklılık (Facione, Facione ve Sanchez, 1994; Park ve Kwon, 2007;) boyutları üzerinden hazırlanmıştır. Buna bağlı olarak, nedenleri 
ya da gerekçeleri sorgulama, doğruyu arama, açık fikirlilik, meraklılık ve dürüstlük (tarafsızlık) boyutlarına göre ilgili literatür ve çalışmalar incelenmiştir. Ölçek maddeleri hazırlanırken bir çok araştırmacının çalışmalarından (Erwin, 1983; Epstein ve Meier, 1989; Good, 2011; Paulhus ve Reid, 1991; Stanovic ve West, 1997; Troldahl ve Powell, 1965) yararlanılmakla birlikte eğitim bilimleri alanında 2 uzman görüşüne başvurulmuştur. Elde edilen ölçek 5'li likert tipinde olup Hiç (1), Nadiren (2), Bazen (3), Genellikle (4), Sık sık (5) şeklinde derecelendirilmiştir. Ölçeğin Açımlayıcı Faktör Analizi (AFA) ve güvenilirlik sonuçlarına ilişkin bilgiler, Tablo 2'de sunulmuştur.

Tablo 2

Eleştirel Düşünme Eğilimleri Ölçeğinin Geçerlik ve Güvenilirlik Sonuçları.

\begin{tabular}{lccccc}
\hline Boyutlar & $\begin{array}{c}\text { Madde } \\
\text { Sayısı }\end{array}$ & $\begin{array}{c}\text { Cronbach } \\
\text { Alpha }\end{array}$ & $\begin{array}{c}\text { Açıklanan } \\
\text { Varyans (\%) }\end{array}$ & Öz değer & Faktör yükleri \\
\hline Nedensel & 6 & .672 & 24.609 & 3,445 & $.692, .685, .556, .533$, \\
düşünme & & & & & $.474, .418$ \\
Meraklılık & 4 & .620 & 12.001 & 1,680 & $.772, .707, .616, .559$ \\
Açık fikirlilik & 4 & .625 & 8.617 & 1,206 & $.684, .668, .617, .556$ \\
Toplam & 14 & .757 & 45.227 & & \\
\hline
\end{tabular}

KMO: .739; Barletts' TS х2 : 680,046; sd: 91; p: .000

Tablo 2 incelendiğinde ölçeğin toplamda 14 maddeden oluştuğu; öz değeri 1'den büyük olan nedensel düşünme (6 madde), meraklılık (4 madde) ve açık görüşlülük (4 madde) boyutlarında toplandığı tespit edilmiştir. Ölçeğin tümü $(\alpha=.757)$ ve alt boyutları için hesaplanan güvenilirlik katsayıları sırasıyla $.672, .620, .625$ olarak bulunmuştur. Ölçeğin, AFA ile elde edilen yapısını doğrulamak için yapılan Doğrulayıcı Faktör Analizi Sonuçları ise Tablo 3'te sunulmuştur.

Tablo 3

Ölçeğin Doğrulayıcı Faktör Analizine Iilişkin Uyum Değerleri.

\begin{tabular}{lcccccc}
\hline \multicolumn{7}{c}{ CMIN: 142,678; sd: 74; p: .000 } \\
\hline CMIN/sd & GFI & AGFI & IFI & CFI & RMSEA \\
\hline Bulunan değer & 1,928 & .94 & .91 & .88 & .88 & .059 \\
* Kriter değer & $\leq 4-5$ & $.85-.89$ & $.85-.89$ & $.90-.94$ & $\geq .95$ & $.06-.08$ \\
\hline \multicolumn{5}{c}{ Ölçek Maddelerinin Standartlaştırılmış Regresyon Ağırlıkları } \\
\hline \multicolumn{7}{c}{ Medensel düşünme } \\
$.58, .51, .50, .46, .55, .47$ & \multicolumn{5}{c}{$.61,68, .37, .54$} & Meraklılık \\
\hline
\end{tabular}

*Kaynak: Meydan, C.H. ve Şeşen, H. (2010). Yapısal Eşitlik Modeli Uygulamaları. Ankara: Detay Yayıncılık

Tablo 3 incelendiğinde Doğrulayıcı Faktör Analizine ilişkin uyum değerlerinin (CMIN/sd=1,928; $\mathrm{GFI}=.94 ; \mathrm{AGFI}=.91 ; \mathrm{IFI}=.88 ; \mathrm{CFI}=.88 ; \mathrm{RMSEA}=.059$ ) ölçeğin açımlayıcı faktör analizinde elde edilen boyutlarını ve maddelerin birbirleriyle olan tutarlılığını doğrular nitelikte olduğu söylenebilir (Meydan ve Şeşen, 2010).

\section{Graja-Reichmann öğrenme stilleri ölçeği}

Graja-Reichmann tarafından geliştirilen ve Koçak (2007) tarafından Türkçe'ye uyarlanmış olan öğrenme stilleri ölçeğinin 42 madde ve 6 boyutta (Bağımsız, Bağımlı, Pasif, İşbirlikli, Rekabetçi ve Katılımcı) oluştuğu tespit edilmiştir. Ölçeğin toplam ve alt boyutlarının güvenilirlikleri sırasıyla .83, .70, $.76, .77, .78, .67$ olarak hesaplanmıştır. Ölçeğin çalışmada yapı geçerliliği yapılmadığı için, lise öğrencilerine uygulanmak üzere bu araştırma için de geçerlik ve güvenilirlik analizine tabi tutulmuştur. Elde edilen ölçek 5'li likert tipinde olup, Kesinlikle katılmıyorum (1), Katılmıyorum (2), Kararsızım (3), 
Katılıyorum (4), Kesinlikle katılıyorum şeklinde derecelendirilmiştir. Ölçeğin Açımlayıcı-Doğrulayıcı faktör analizi ve güvenilirlik analizi sonuçlarına ilişkin bilgiler, Tablo 4 ve Tablo 5 'te sunulmuştur.

Tablo 4

Öğrenme Stilleri Ölçeğinin Geçerlik ve Güvenilirlik Analizi Sonuçları.

\begin{tabular}{lccccc}
\hline Boyutlar & $\begin{array}{c}\text { Madde } \\
\text { Sayısı }\end{array}$ & $\begin{array}{c}\text { Cronbach } \\
\text { Alpha }\end{array}$ & $\begin{array}{c}\text { Açılanan } \\
\text { Varyans (\%) }\end{array}$ & Özdeğer & Faktör yükleri \\
\hline Sistemli Çalışma & 5 & .716 & 24,110 & 3,858 & $.733, .726, .712, .686$, \\
& & & & & .549 \\
Öğretmene & 4 & .705 & 11,632 & 1,861 & $.772, .731, .705, .633$ \\
bağımlılık & & & & & \\
Sınıf içi işbirliği & 4 & .645 & 10,599 & 1,696 & $.815, .779, .544, .516$ \\
$\begin{array}{l}\text { Rekabetçi } \\
\text { Toplam }\end{array}$ & 3 & .693 & 8,783 & 1,405 & $.821, .785, .716$ \\
\hline
\end{tabular}

KMO: .764; Barletts' TS х2: 882,093; df: 120; p: .000

Tablo 4 incelendiğinde ölçeğin toplamda 16 maddeden oluştuğu; öz değeri 1'den büyük olan sistemli çalışma (5 madde), öğretmene bağımlı olma (4 madde), sınıf içi işbirliği (4 madde) ve rekabetçi (3 madde) boyutlarında toplandığı tespit edilmiştir. Ölçeğin tümü ( $\alpha=.779)$ ve alt boyutları için hesaplanan güvenilirlik katsayıları sırasıyla .716, .705, .645, ve .693 olarak bulunmuştur. Ölçeğin, AFA ile elde edilen yapısını doğrulamak için yapılan Doğrulayıcı Faktör Analizi Sonuçları, Tablo 5 'te sunulmuştur.

Tablo 5

Ölçeğin Doğrulayıcı Faktör Analizine Iilişkin Uyum Değerleri.

\begin{tabular}{|c|c|c|c|c|c|c|}
\hline \multicolumn{7}{|c|}{ CMIN: 159,$342 ;$ sd: 99; p: .000 } \\
\hline & CMIN/sd & GFI & AGFI & $\mathrm{IFI}$ & $\mathrm{CFI}$ & RMSEA \\
\hline Bulunan değer & 1.610 & .93 & .91 & .93 & .93 & .048 \\
\hline *Kriter değer & $\leq 4-5$ & $.85-.89$ & $.85-.89$ & $.90-.94$ & $\geq .95$ & $.06-.08$ \\
\hline \multicolumn{7}{|c|}{ Ölçek Maddelerinin Standartlaştırılmış Regresyon Ağırlıkları } \\
\hline $\begin{array}{c}\text { Sistemli çalışma eğilimi } \\
.45, .54, .62, .63, .67\end{array}$ & $\begin{array}{r}\text { Öğretmen } \\
.60, .6\end{array}$ & $\begin{array}{l}\text { mlılık } \\
.60\end{array}$ & $\begin{array}{l}\text { Sınıf içi iş } \\
.41, .53, .\end{array}$ & & & \\
\hline
\end{tabular}

*Kaynak: Meydan, C.H. ve Şeşen, H. (2010). Yapısal eşitlik modeli uygulamaları. Ankara: Detay Yayıncılık.

Tablo 5 incelendiğinde Doğrulayıcı Faktör Analizine ilişkin uyum değerlerinin (CMIN/sd=1,610; $\mathrm{GFI}=.93 ; \mathrm{AGFI}=.91 ; \mathrm{IFI}=.93 ; \mathrm{CFI}=.93 ; \mathrm{RMSEA}=.048)$ ölçeğin açımlayıcı faktör analizinden elde edilen boyutlarını ve maddelerin birbirleriyle olan tutarlılığını doğrular nitelikte olduğu söylenebilir (Meydan ve Şeşen, 2010).

\section{Verilerin Analizi}

iliş̧kisel modelde desenlenen bu araştırmada öğrenme stillerinin alt boyutları (Sistemli çalışma eğilimi, öğretmene bağımlı olma, sınıf içi iş birliği, rekabetçi) bağımsız değişken; eleştirel düşünme eğilimlerinin alt boyutları (nedensel düşünme, meraklılık, açık görüşlülük) bağımlı değişkenler olarak ele alınmıştır. Bu doğrultuda lise öğrencilerinin öğrenme stillerinin eleştirel düşünme eğilimlerini açıklama gücünü tespit etmek amacıyla Çoklu Doğrusal Regresyon Analizi tekniği kullanılmıştır. Ayrıca regresyon modeline tabi tutulan bağımsız değişkenlerin alt boyutları üzerinde çoklu bağlantı oluşturup oluşturmadığını test etmek için Pearson Momentler Çarpım Korelasyon tekniği kullanılmıştır. Çoklu bağlantı probleminden kaçınmak için bağımsız değişkenlerin alt boyutları arasında korelasyonlar .80'in altında olmalıdır (Licht, 1998). Bu duruma ilişkin korelasyon ve betimleyici istatistikler, Tablo 6'da sunulmuştur. 


\section{Bulgular}

Öğrenme stillerinin sistemli çalışma boyutu ile nedensel düşünme $(r=175, p<.01)$ ve açık görüşlülük $(r=.385, p<.01)$ boyutları arasında pozitif yönde anlamlı ilişkiler olduğu görülürken, sistemli çalışma ile meraklılık ( $r=.030, p>.05)$ boyutu arasında anlamlı ilişkinin bulunmadığı saptanmıştır. Öğrenme stilleri alt boyutlarından öğretmene bağımlı olma boyutu ile nedensel düşünme $(r=.498, p<.01)$, meraklıık ( $r=.321$, $p<.01)$ ve açık görüşlülük $(r=.371, p<.01)$ boyutları arasında anlamlı pozitif ilişkilerin olduğu tespit edilmiştir. Diğer yandan, öğrenme stillerinde sınıf içi iş birliği boyutu ile nedensel düşünme $(r=.284$, $p<.01)$, meraklılık ( $r=.351, p<.01)$ ve açık görüşlülük $(r=.292, p<.01)$ boyutları arasındaki ilişki ise anlamlı ve pozitif yöndedir. Bununla birlikte rekabetçi stili boyutu ile nedensel düşünme ( $r=.086, p>.05)$, meraklılık ( $r=.064, p>.05)$ ve açık görüşlülük $(r=.088, p>.05)$ boyutları arasındaki ilişkilerin ise anlamlı olmadığı bulunmuştur.

Tablo 6

Regresyon Modeline Tabi Tutulan Değişkenlerin Korelasyon Matrisi ve Betimleyici Istatistik Değerleri.

\begin{tabular}{|c|c|c|c|c|c|c|c|c|c|}
\hline & $x$ & S.S. & 1 & 2 & 3 & 4 & 5 & 6 & 7 \\
\hline $\begin{array}{l}\text { 1-Nedensel } \\
\text { düşünme }\end{array}$ & 4,07 & 63 & 1 & & & & & & \\
\hline 2-Meraklılık & 3,99 & ,72 &, $345(* *)$ & 1 & & & & & \\
\hline $\begin{array}{l}\text { 3-Açık } \\
\text { görüşlülük }\end{array}$ & 3,68 & ,78 &, $462(* *)$ &, $231(* *)$ & 1 & & & & \\
\hline $\begin{array}{l}\text { 4-Sistemli } \\
\text { çalışma }\end{array}$ & 3,06 & 90 &, $175(* *)$ & ,030 &, $385(* *)$ & 1 & & & \\
\hline $\begin{array}{l}\text { 5-Öğretmene } \\
\text { bağımlılık }\end{array}$ & 4,19 & ,77 &, $498(* *)$ &, $321(* *)$ &, $371(* *)$ &, $265(* *)$ & 1 & & \\
\hline $\begin{array}{l}\text { 6-Sınıf içi } \\
\text { işbirliği }\end{array}$ & 3,48 & ,92 &, $284\left(^{* *}\right)$ &, $351(* *)$ &, $292(* *)$ &, $259(* *)$ &, $271(* *)$ & 1 & \\
\hline 7-Rekabetçi & 3,37 & 1,11 & ,086 & ,064 & ,088 &, $253(* *)$ &, $189(* *)$ &, $132\left(^{*}\right)$ & 1 \\
\hline
\end{tabular}

Lise öğrencilerinin öğrenme stillerinin (sistemli çalışma, öğretmene bağımlılık, sınıf içi iş birliği, rekabet) eleştirel düşünme eğilimlerini yordama düzeyini belirlerken öncelikle eleştirel düşünme eğilimi toplam puanları, sonra sırasıyla nedensel düşünme, meraklıık ve açık görüşlülük alt boyutları üzerinde regresyon analizleri yapılmıştır.

\section{Toplam Eleştirel Düşünme Eğilimleri}

Öğrenme stillerinin Toplam Eleştirel Düşünme Eğilimleri boyutunu yordamasına ilişkin Çoklu Doğrusal Regresyon Analizi sonuçları, Tablo 7'de verilmiştir.

Tablo 7:

Toplam Eleştirel Düşünme Eğilimlerinin Yordanmasına IIlişkin Regresyon Sonuçları.

\begin{tabular}{lcccccc}
\hline Değişken & B & Sh & Beta & t & (p) & Kısmi korelasyon \\
\hline (Sabit) & 1,978 &, 169 & & 11,68 &, 000 & \\
Sistemli çalışma &, 037 &, 032 &, 061 & 1,15 &, 249 & .072 \\
Öğretmene &, 316 &, 036 &, 457 & 8,67 &, 000 & .475 \\
bağımlılık &, 160 &, 031 &, 271 & 5,18 &, 000 & .307 \\
Sınıf içi işbirliği &,- 004 &, 025 &,- 009 &,- 17 &, 867 & -.010 \\
Rekabet &
\end{tabular}

a) Bağımlı değişken: Eleştirel Düşünce Toplam Puanları 
Tablo 7'de görüldüğü üzere, lise öğrencilerinin öğrenme stilleri, eleştirel düşünme eğilimlerini anlamlı bir şekilde yordamaktadır $\left(R=.611, R^{2}=.374, F=38,660, p<.05\right)$. Çoklu regresyon analizi sonuçlarına göre öğrenme stillerinin eleştirel düşünme eğilimlerinin \% 37'sini açıkladığı tespit edilmiştir. Standardize edilmiş regresyon katsayılarının anlamlılığına ilişkin sonuçlar incelendiğinde, lise öğrencilerinin öğretmene bağlı olarak çalışma $(\beta=, 457, p<.05)$ ve sınıf içi etkinliklerde iş birliği halinde olma $(\beta=, 271$, $p<.05)$ öğrenme stilleri, eleştirel düşünme eğilimlerini anlamlı ve pozitif yönde yordadığı saptanmıştır. Bulgular, lise öğrencilerinin öğretmene bağlı olarak çalışma ve sınıf içi etkinliklerde iş birliği halinde olma durumları arttıkça, eleştirel olarak düşünme eğilimlerinin de arttığını göstermektedir. Diğer yandan, sistematik ve düzenli olarak çalışma ile rekabete dayalı bir çalışma stillerinin eleştirel düşünme eğilimlerini anlamlı bir şekilde yordamadığı saptanmıştır ( $p>.05)$. Lise öğrencilerinin öğrenme stillerinin nedensel düşünme boyutunu yordamasına ilişkin Çoklu Doğrusal Regresyon Analizi sonuçları, Tablo 8’de verilmiştir.

\section{Nedensel Düşünme}

Tablo 8

Nedensel Düşünmenin Yordanmasına iliş̧kin Regresyon Sonuçları.

\begin{tabular}{lcccccc}
\hline Değişken & B & Sh & Beta & t & (p) & Kısmi korelasyon \\
\hline (Sabit) & 2,102 &, 216 & & 9,72 &, 000 & \\
Sistemli çalışma &, 010 &, 040 &, 015 &, 26 &, 796 & .016 \\
Öğretmene bağımlılık &, 370 &, 046 &, 450 & 7,96 &, 000 & .443 \\
Sınıf içi işbirliği &, 118 &, 039 &, 169 & 3,00 &, 003 & .183 \\
Rekabet &,- 007 &, 032 &,- 012 &,- 22 &, 828 & -.014 \\
\hline
\end{tabular}

a) Bağımlı değişken: Nedensel düşünme

Tablo 8'de görüldüğü üzere, lise öğrencilerinin öğretmene bağımlı olarak çalışma ve sınıf içi iş birliği halinde olma stilleri, eleştirel düşünme eğilimlerine ilişkin nedensel düşünme eğilimini anlamlı ve pozitif yönde yordamaktadır $\left(R=.524 ; R^{2}=.275 ; F=24,559 ; p<.05\right)$. Çoklu regresyon analizi sonuçlarına göre öğrenme stillerinin nedensel düşünme eğiliminin \%28'ini açıkladığı tespit edilmiştir. Standardize edilmiş regresyon katsayılarının anlamlılığına ilişkin sonuçlar incelendiğinde, lise öğrencilerinin öğretmene bağlı olarak çalışma stili $(\beta=.450 ; p<.05)$, nedensel düşünme eğilimini anlamlı ve pozitif yönde yordamaktadır. İkinci olarak regresyon eşitliğinde, lise öğrencilerin diğer öğrencilerle sınıf içerisinde iş birliği halinde olmaları ( $\beta=.169 ; p<.05)$, nedensel düşünme eğilimlerini anlamlı ve pozitif yönde yordadığı saptanmıştır. Bu bulgular, lise öğrencilerinin öğretmene bağımlı olarak çalışma ve diğer arkadaşları ile birlikte sınıf içi etkinliklerine katılma durumları ya da halleri arttıkça, nedensel olarak düşünme eğilimlerinin arttığını göstermektedir. Diğer yandan, sistemli çalışma ve rekabete dayalı bir öğrenme stilinin ise, nedensel düşünme eğilimini anlamlı olarak yordamadığı saptanmıştır (p>.05). Öğrenme stillerinin meraklıık boyutunu yordamasına ilişkin Çoklu Doğrusal Regresyon Analizi sonuçları Tablo 9'da verilmiştir.

\section{Meraklılık}

Tablo 9

Meraklılık Boyutunun Yordanmasına ilişkin Regresyon Sonuçları

\begin{tabular}{lcccccc}
\hline & B & Sh & Beta & t & (p) & Kısmi korelasyon \\
\hline (Sabit) & 2,311 &, 259 & & 8,94 &, 000 & \\
Sistemli çalışma &,- 108 &, 048 &,- 133 & $-2,22$ &, 027 & -.137 \\
Öğretmene bağımlılık &, 244 &, 056 &, 261 & 4,39 &, 000 & .264 \\
Sınıf içi işbirliği &, 256 &, 047 &, 321 & 5,44 &, 000 & .320 \\
Rekabet &, 028 &, 039 &, 042 &, 72 &, 470 & .045 \\
\hline
\end{tabular}

Bağımlı değişken: Meraklılık 
Tablo 9'da görüldüğü üzere, lise öğrencilerinin sistematik çalışma eğilimi, öğretmene bağlı olarak çalışma ve sınıf içi işbirliği halinde olma stilleri, eleştirel düşünmeye ilişkin meraklılık eğilimini anlamlı bir şekilde yordamaktadır $\left(\mathrm{R}=.448, \mathrm{R}^{2}=.201, \mathrm{~F}=16,280, \mathrm{p}<.05\right)$. Çoklu regresyon analizi sonuçlarına göre öğrenme stillerinin meraklılık eğilimlerinin \% 20'sini açıklamaktadır. Standardize edilmiş regresyon katsayılarının anlamlılı̆̆na ilişkin sonuçlar incelendiğinde, lise öğrencilerinin sistematik çalışma biçimleri $(\beta=-133, p<.05)$ meraklılık eğilimlerini anlamlı ve negatif yönde yordarken, öğretmene bağlı olarak çalışma $(\beta=, 261, p<.05)$ ve sınıf içi etkinliklerde iş birliği halinde olma stilleri $(\beta=, 321, p<.05)$ anlamlı ve pozitif yönde yordadığı saptanmıştır. Bu bulgular, lise öğrencilerinin sistematik ve düzenli bir şekilde çalışma eğilimleri arttıkça günlük hayatta gerçekleşen olaylara ilişkin meraklarının azaldığı; öğretmene bağı bir şekilde çalışma ve sınıf içi etkinliklerde işbirliği halinde olma biçimleri arttıkça, günlük hayatta gerçekleşen olaylara ilişkin meraklarının arttığını göstermektedir. Diğer yandan, lise öğrencilerinin rekabete dayalı çalışma biçimlerinin $(\beta=, 042, p>$.05) meraklılık eğilimlerini anlamlı bir şekilde yordamadığı saptanmıştır. Lise öğrencilerinin öğrenme stillerinin açık fikirlilik eğilimlerini yordama düzeyine ilişkin Çoklu Regresyon Analizi sonuçları, Tablo 10'da sunulmuştur.

\section{Açık Fikirlilik}

Tablo 10

Öğrenme Stillerinin Açık Fikirlilik Boyutunu Yordama Düzeyi.

\begin{tabular}{lcccccc}
\hline & B & Sh & Beta & t & (p) & Kısmi korelasyon \\
\hline (Sabit) & 1,438 &, 270 & & 5,32 &, 000 & \\
Sistemli çalışma &, 246 &, 051 &, 284 & 4,87 &, 000 & .290 \\
Öğretmene bağımlılık &, 261 &, 058 &, 259 & 4,49 &, 000 & .269 \\
Sınıf içi işbirliği &, 133 &, 049 &, 155 & 2,70 &, 007 & .166 \\
Rekabet &,- 020 &, 040 &,- 027 &,- 48 &, 628 & -.030 \\
\hline
\end{tabular}

a) Bağımlı değişken: Açık fikirlilik

Tablo 10'da görüldüğü üzere, lise öğrencilerinin öğrenme stillerinin eleştirel düşünme eğilimlerine ilişkin açık görüşlülük boyutunu anlamlı bir şekilde yordadığı saptanmıştır $\left(R=.498, R^{2}=.248, F=21,336\right.$, $\mathrm{p}<.05)$. Çoklu regresyon analizi sonuçlarına göre öğrenme stillerinin açık fikirlilik eğiliminin \% 25 'ini açıkladığı tespit edilmiştir. Standardize edilmiş regresyon katsayılarının anlamlılı̆̆na ilişkin sonuçlar incelendiğinde, lise öğrencilerinin sistemli olarak çalışma eğilimi $(\beta=, 248, p<.05)$, öğretmene bağlı olarak çalışma $(\beta=, 259, p<.05)$ ve sınıf içi etkinliklerde işbirliği halinde olma $(\beta=, 155, p<.05)$ stillerinin, açık fikirlilik eğilimini anlamlı ve pozitif yönde yordadığı saptanmıştır. Bulgular, lise öğrencilerinin sistematik ve düzenli olarak çalışma, öğretmene bağlı olarak çalışma ve sınıf içi etkinliklerde işbirliği halinde olma eğilimleri arttıkça, farklı görüş, düşünce ve fikirlere açık olma eğilimlerinin de arttığını göstermektedir. Diğer yandan, rekabete dayalı bir çalışma $(\beta=,-027, p>.05)$ biçiminin açık görüşlülük boyutunu anlamlı bir şekilde yordamadığı bulunmuştur.

\section{Sonuç, Tartışma ve Öneriler}

Araştırmada lise öğrencilerinin öğrenme stilleri ile eleştirel düşünme eğilimlerini arasında nedensellik ilişkisi bağlamında öğrenme stillerinin eleştirel düşünme eğilimlerini yordama durumu incelenmiştir. Nedensellik ilişkisinin kurulduğu araştırmalarda iki değişken arasında anlamlı ilişkilerin var olması gerekir (Cole, 1999). Bu bağlamda çalışmada öğrenme stilleri ile eleştirel düşünme eğilimleri arasında anlamlı pozitif ilişkiler tespit edilmiştir. Sadece öğrenme stilleri alt boyutlarından rekabetçi stilin eleştirel düşünme eğilimleri ile anlamlı bir ilişkisinin olmadığı görülmüştür. Yapılan çalışmalar da öğrenme stilleri ile eleştirel düşünme eğilimleri arasındaki ilişkiyi kuramsal ve ampirik bulgularla destekler niteliktedir (Güven ve Kürüm, 2004; Mahmoud, 2012; An ve Yoo, 2008; Beşoluk ve Önder, 2010; Sulaiman, Rahman ve Dzulkifli, 2008; Zarbakhsh ve diğerleri, 2012; Colucciello, 1999; Zhang ve Lambert, 2008). 
Bulgular, lise öğrencilerinin öğrenme stillerinin eleştirel düşünme eğilimlerini anlamlı olarak yordadığını göstermektedir. Benzer şekilde bu çalışma ile paralel olarak Torres ve Cano (1995)'nun yaptıkları çalışmada öğrenme stillerinin eleştirel düşüncenin \% 9.1'ini açıkladığı ve .30 düzeyinde anlamlı olarak yordadığı tespit edilmiştir. Çalışmada öğrenme stili alt boyutlarından öğretmene bağımlı olma (öğretmenin sınıf içerisinde ders ve ödevlerle ilgili olarak öğrencilere nelerin yapılacağı ya da yapılmayacağı konusunda gerekli açıklamalar ve bilgilerin verilmesi vb.), sistemli çalışma eğilimi (ödevleri düzenli ve zamanından önce yapma, ön sıralarda oturma ve not alma vb) ve sınıf içi işbirliği stilleri öğrencilerin eleştirel düşünme eğilimlerini yordayıcı etkisinin olduğu görülmektedir. Buna bağlı olarak öğretmene bağımlı olma, sistematik çalışma ve sınıf içi iş birliği stillerinin, lise öğrencilerinin eleştirel düşünme eğilimleri üzerinde özellikle gerekçelere bağlı olarak nedensel düşünme, dünyada meydana gelen olaylar, yenilikler ve entelektüel bir takım etkinliklere karşı merakıılığını ve çevresindeki karşıt düşüncelere sahip olan insanları dinleme, fikir ve düşüncelere saygı duymaya yönelik açık fikirliliğini yordayııı etkisinin olduğu söylenebilir.

Bulgular, sistemli çalışma stilinin eleştirel düşünme eğilimlerini anlamlı bir şekilde yordadığını göstermiştir. Sistemli çalışma stili, öğrencilerin ödevleri düzenli ve zamanından önce yapma, ön sıralarda oturma, not alma gibi öğrencinin sınıf içerisinde ve dışında aktif olarak öğrenme sürecine katılmasını ifade eder. Bu bağlamda yapılandırmacı bir öğrenme ortamı da aktif bir öğrenmeyi işaret ederken, öğrencilerin öğrenmeye motive olmuş etkin bir katılımcılı̆̆ını gerektirmektedir. Micheal ve Modell (2003)'e göre öğrencileri böyle bir ortama katılmaya hazırlarken öğretmenlerin sınıf ortamını öğrenmeye teşvik edici hale getirmeli ve öğrencilerin katılımının ne kadar değerli olduğunu hissettirmelidir. Buna göre öğretmenler bunu başarabilirlerse, tüm öğrencilerin bu süreçte aktif olacağı ve öğrenmenin zevkli hale geleceği motive olmuş bir öğrenme ortamı oluşturmuş olacaklardır. Schunk (2009) ise pek çok değişkenin öğrencinin motivasyonunu etkileyebileceğini ve öğrenciler bir materyali öğrenme, iyi bir performans gösterme ve ödevi ilk bitiren kişi olma hedefleri ile göreve başladığını ifade etmektedir. Schunk'ın motivasyonal öğrenme modelinde öğrencilerin bir göreve başlamadan önce hedefler ve beklentilerin (öz yeterlik, sonuçlar vb.) ortaya konulması ve öğrencilerin ihtiyaç duyduğu değerler, duygular, ihtiyaçlar ve sosyal desteğin sağlanması gerektiğine vurgu yapılmaktadır. Bu çerçevede öğrenciler kendi öğrenme sorumluluğunu alarak daha etkin, disiplinli ve sistematik bir çalışma biçimi içerisinde yer alırlar. Ele alınan hususlar bağlamında öğrencilerin daha eleştirel olarak düşünme eğilimi sergilemeleri mümkün görünmektedir.

Bulgular, öğretmene bağımlı öğrenme stilinin eleştirel düşünme eğilimlerini anlamlı bir şekilde yordadığını göstermiştir. Öğretmene bağımlı olma stili, öğrencinin merak düzeyinin çok az olduğu, ancak öğretmenin sınıf içerisinde ders ve ödevlerle ilgili olarak öğrencilere nasıl yapılacağı konusunda detaylı açıklamaların yapılması, öğretmenin sınıf içerisinde dersin özeti ve önemli notları yazmasına bağlı olarak öğrencilerin öğrenmesini esas alır (Grasha ve Reichmann, 1974). Öğretmen, anlamı ve anlayışı yapılandırma sürecinde kolaylaştırıcı bir etken olarak görülür (Prithchard ve Woolard, 2009). Bu süreçte öğrencinin gerekli öğrenmeleri nasıl gerçekleştireceği ve hangi yolları izleyeceği öğretmenin rehberliğine bağlı olarak gerçekleşir. D’Angelo, Touchman ve Clark (2009), yapılandırmacı bir öğretimde öğretmenin yönlendirici rehberliğinin öğrencinin gelişiminde önemli olduğuna vurgu yapmıştır. Ancak böyle bir yaklaşım öğretmenin doğrudan bir öğretim sergilediği bir yöntem olsa da, Taylor ve MacKenney (2008)'e göre doğrudan öğretim ile öğretmen, öğrencilerin belli bir konu hakkında öğreneceği temel bilgileri sağlayarak arzu edilen değişimi sağlamasına yardım eder. Bu sayede konu üzerinde çalışırken temel becerileri kazanması sağlanabilir.

Bulgular, işbirlikli öğrenme stilinin eleştirel düşünme eğilimlerini yordayıcı etkisinin olduğunu göstermiştir. Yapılan çalışmalar öğrencilerin akranlarıyla etkileşime girdiklerinde daha fazla sosyal ilişkiler kurduklarını, kişiler arası çatışmalar çözmede daha fazla istekli olduklarını ve zihinsel işlem gerektiren etkinliklerde bireysel öğrenenlere oranla daha üretken ve kaynakları daha etkili kullandıklarını göstermektedir (Ryan, 2009). Vygotsky'nin sosyo-kültürel teorisine göre, öğrenme büyük oranda sosyal bir aktivitedir ve tam bir bilişsel gelişim, sosyal bir etkileşimi gerektirir. Böyle bir etkileşimde öğrencilerin 
bilgi ve anlamalarının gelişimi için düşünme, fikir ve etkinliklere katılımla zihinsel gelişimi sağlayan bir paylaşım alanı içerisinde olunmalıdır (Prithchard ve Woolard, 2009). Ancak işbirlikli öğrenme ortamlarında öğrenciler kendileri için anlamlı, ilgi ve değeri olan öğrenme aktivitelerine zihinsel bir katııımdan (tartışma, problemle ilgili olma vb.) ziyade fiziksel katıım (arkadaşına yardım etme, saygı duyma vb.) eğilimlerini sergilemektedir (Turkanis, Barlett ve Rogoff, 2001). Bu nedenle zihinsel gelişimleri için gerekli düşünme etkinliklerinin sağlanamaması işbirlikçi öğrenme ortamlarının verimsiz gerçekleşmesine neden olabilmektedir. Öğrenme gruplarının dengeli bir şekilde katııımı ile tüm öğrencilerin sınıf içi tartışmaya katkı sağlaması ve bu süreçte sosyal ve bilişsel stratejilerden (problem çözme, proje tabanlı öğretim) yüksek oranda faydalanılması sağlanabilir (Chinn ve Chinn, 2009). Marzano, Pickering ve Pollock (2001)'un yaptıkları meta-analiz çalışmasında öğrencilerin işbirlikçi öğrenme ortamlarında öğrencilerin 3-4'erli (Etki büyüklüğü, EB: ,22) bir şekilde gruplandırılmasının ikili (EB:15) ve 5-7 (EB: -.02)'li gruplara oranla daha etkili olduğu görülmüştür. Yine bu çalışmada öğrencilerin düşük (EB:-.60) ve yüksek (EB:.09) düzeyde zihinsel yeteneğe sahip olanların kendi aralarında grup oluşturulması, heterojen gruplara oranla etkisiz bir gruplama olduğu görülürken, orta düzeydeki (EB:.51) öğrencilerin bir arada olmasının ise, yeteneğe göre heterojen bir gruplamaya oranla daha etkili olduğu saptanmıştır.

Bulgular, rekabetçi öğrenme stilinin eleştirel düşünme eğilimlerini anlamlı bir şekilde yordamadığını göstermiştir. Teorik çerçevede rekabetçi anlayışın sonuçları sosyolojik olarak tartışılmaktadır. Bu çerçevede rekabetçi anlayış, sanayileşmenin yükselmesiyle giderek artan iş gücü ve buna bağlı olarak işçi gereksinimi ile hızla artan ekonomik bir rekabeti oluşturmuştur. Bu bağlamda okulların var olma nedeni, bu rekabetçi sistem içerisinde sadece intiyaçları karşılayan bireyler yetiştirmedir. Bu sistemin ürünleri olarak sadece belli karakter özelliklere sahip insan modeli ön görülmektedir. Sistemin arzu ettiği tek tip insan modeli, istenileni yerine getiren ve pasif bireyler yetiştirmeyi hedeflemiştir (Spring, 2010). Freire, bu durumu bir tür insanları uyarlanan, etki altına alan bankacı eğitim modeli olarak görmektedir. Ona göre öğrencilere yüklenen yığmacı bilgi anlayışı ve kendilerine dayatılan edilgen rol, dünyayı o haliyle algılamasına neden olmaktadır. Daha ziyade yaşadığı dünyanın gerçekliğini görüp, herhangi bir müdahale sergilenemediğinde eleştirel bilinçleri gelişmeyecektir (Freire, 2011). Nitekim böyle bir eğitim modelinde ülkemizde de olduğu gibi öğrencileri yarıştıran çoktan seçmeli sınavların uygulanması, rekabetçi bir ortam oluşturmaktadır. Yapılan bir çalışmada ise çoktan seçmeli sınavların eleştirel düşünme becerilerini geliştirmediği ortaya çıkmaktadır (Ennis, 1996). Yapılan çalışmalarda rekabete dayalı ortamlarda verilen eğitim öğrencilerin başarılarını olumsuz yönde etkilediği bulunmuştur. Öğrenciler bu sistem içerisinde başarısız oldukça daha da rekabetçi olma eğilimindedirler (Fraja ve Landeras, 2006; Jayant, Karandikar ve Krishnan, 1984). Johnson ve Johnson (1979)'ın çalışmasında ise işbirliği, rekabet ve bağımsız çalışma ortamlarında öğrencilerin problem çözme gibi zihinsel aktiviteleri incelenmiştir. Araştırmaya göre, işbirliği içerisinde olan öğrencilerin, rekabetçi ve bağımsız öğrenme ortamında olanlara oranla problem çözme yeteneklerinin yüksek olduğu ve daha başarıı oldukları saptanmıştır. Bu durum çerçevesinde rekabete dayalı bir anlayışın öğrenme üzerinde etkili bir yöntem olmadığı, daha ziyade kapital bir amacı öngören mekanizmalarda etkin olduğu söylenebilir.

Ortaya konulan sonuçlardan hareketle öğrenme stilleri, öğrenmenin doğası ve yapısı bağlamında ele alınmıştır. Bu çerçevede öğretmenin sınıf içerisinde ip uçlarının verdiği, öğretmen direktifli bir öğrenme stili, sınıf içerisinde öğrencilerin iş birliği içerisinde öğrenme stili ve sistemli çalışma stillerinin, öğrencilerin eleştirel düşünme eğilimlerini açıklamadaki gerekçeleri teorik ve empirik bulgulara dayalı olarak tartışılmıştır. Öğrencilerin eleştirel olarak düşünme eğilimleri sergilemeleri, öğrenmede mevcut öğrenme stilleri, biçimleri ya da ortamlarının farkındalığı ve uygulanmalı ile gerçekleştirilmesi mümkün görünmektedir. 


\section{Kaynakça}

Agarwal, R. ve Jaiswal, D. (2010). Learning style preferences of adolescents in relation to their mental ability. Journal of Educational Research, 13 (2), 108-113.

Ahmad, N. A., Jelas, Z. M. ve Ali, M. M. (2011). The relationship between learning styles and strategies with academic achievement based on gender and type of school. The International Journal of Learning, $17(10), 265-278$.

An, G. J. ve Yoo, M. S. (2008). Exploring the relationship between learning style and critical thinking in an online course. Contemporary Nurse Journal, 29 (1), 100-109.

Bailin, S., Case, R., Coombs, J. R. ve Daniels, L.B. (1999). Conceptualizing critical thinking. Journal of Curriculum Studies, 31 (3), 285-302.

Baum, L. M. ve Newbill, P. L. (2010). Instructional design as critical and creative thinking: A journey through a Jamestown-Era Native American Village. TechTrends, 54 (5), 27-37.

Berry, T. ve Settle, A. (2011). Learning style preferences. International Journal of Education Research, 6 (1), 1-8.

Beşoluk, Ş. ve Önder, i. (2010). Investigation of teacher candidates' learning approaches, learning styles and critical thinking dispositions. Elementary Education Online, 9 (2), 679-693.

Büyüköztürk, Ş., Kılıç-Çakmak, E., Akgün, Ö. E., Karadeniz, Ş ve Demirel, F. (2009). Bilimsel Araştırma Yöntemleri (3.Baskı). Ankara: Pegem Akademi.

Chen, Y., Cheng, Y., Liu, K. ve Tsai, H. (2009). Development of the critical thinking disposition inventory. The 74th Annual Meeting of the Psychometric Society, University of Cambridge.

Chinn, C. A. ve Chinn, L. M. (2009). Collaborative Learning. Eric M. Anderman ve Lynley H. Anderman (Eds.), Pschology of Classroom Learning: An Encyclopedia. USA: Macmillan Social Science Library.

Cole, S. (1999). Sosyolojik Düşünme Yöntemi (Bekir Demirkol, Çev.). Ankara: Vadi Yayınları.

Colucciello, M. L. (1999). Relationships between critical thinking dispositions and learning styles. Journal Proffesionals Nursing. 15 (5), 294-301.

D'Angelo, C. M., Touchman, S. ve Clark, D. B. (2009). Construcitivism: Overview. Eric M. Anderman ve Lynley H. Anderman (Eds.), Pschology of Classroom Learning: An Encyclopedia. USA: Macmillan Social Science Library.

Dunn, R. (2000). Capitalizing on College Students' Learning Styles: Theory, Practice, and Research. Rita Dunn ve Shirley A. Griggs (Eds.), Practical Approaches to Using Learning Styles in Higher Education. London: Bergin \& Garvey.

Duron, R., Limbach, B. ve Waugh, W. (2006). Critical thinking framework for any discipline. International Journal of Teaching and Learning in Higher Education, 17 (2), 160-166.

Ennis, R. H. (1996). Critical Thinking. Upper Saddle River, NJ: Prentice-Hall.

Epstein, S. ve Meier, P. (1989). Constructive thinking: A board coping variable with spesific components. Journal Personality and Social Psychology, 57, 332-350.

Erwin, T. D. (1983). The scale of intellectual development: Measuring Perry's scheme. Journal of College Students Personnel, 24, 6-12.

Facione, N, Facione, P ve Sanchez, C. (1994). Critical thinking disposition as a measure of competent clinical judgment: The development of the California Critical Thinking Disposition Inventory. Journal of Nursing Education, 33 (8), 345-350.

Fraja, G. D. ve Landeras, P. (2006). Could do better: The effectiveness of incentives and competition in schools. Journal of Public Economics, 90 (1-2), 189-213.

Freire, P. (2011). Ezilenlerin Pedagojisi (D. Hattatoğlu ve E. Özbek, Çev.). İstanbul: Ayrıntı Yayınları.

Gantasala, P. V. ve Gantasala, S. B. (2009). Influence of learning styles. The International Journal of Learning, 16 (9), 169-184.

Glaser, E. M. (1985). Critical thinking: Educating for responsible citizenship in a democracy. National Forum: Phi Kappa Phi Journal, 65(1), 24-27.

Good, J. L. (2011). Teaching truth-seeking skills. In The American Center For Teaching Critical Thinkingto Students with Learning Disabilities. 02. 10. 2012 tarihinde www.mendeley.com adresinden erişilmiştir.

Govier, T. (1989). Critical thinking as argument Analysis?. Argumentation, 3, 115-126. 
Güven, M ve Kürüm, D. (2004). Öğrenme stilleri ve eleştirel düşünme arasındaki ilişkiye genel bir bakış. XIII. Ulusal Eğitim Bilimleri Kurultayı, İnönü Üniversitesi, Malatya.

Hawkins, j. (2006). Accessing multicultural issues through critical thinking, critical inquiry, and the student research process. Urban Education, 41 (2), 169-191.

Hoaglund, J. (1993). Critical thinking: A socratic model. Argumentation, 7, 291-311.

Irani, T., Rudd, R., Gallo, M., Ricketts, J., Friedel, C., ve Rhoades, E. (2007). Critical thinking instrumentation manual. http://step.ufl.edu/resources/critical_thinking/ctmanual.pdf. adresinden 22.04.2012 tarihinde erişilmiştir.

Jayant, K. R., Karandikar, H. M. ve Krishnan, L. (1984). Success/failure experiences, achievement motivation, and competition in a scarcity culture. The Journal of Social Psychology, 125 (2), 261-263.

Johnson, R. T. ve Johnson, D. W. (1979). Type of task and student achievement and attitudes in interpersonal cooperation, competatition, and individualization. The Journal of Social Psychology, 108, 37-48.

Koçak, T. (2007). İlköğretim 6.7.8. Sınıf Öğrencilerinin Öğrenme Stilleri ve Akademik Başarıları Arasındaki iliş̧ki. Yüksek Lisans Tezi, Gaziantep Üniversitesi, Sosyal Bilimler Enstitüsü, Gaziantep.

Koçakoğlu, M. (2010). Determining the learning styles of elementary school (1st-8th grade) teachers. International Online Journal of Educational Sciences, 2 (1), 54-64.

Komarraju, M., Karau, S. J., Schmeck, R. R. ve Avdic, A. (2011). The Big Five personality traits, learning styles, and academic achievement. Personality and Individual Differences, 51 (4), 472-477.

Kozub, R. M. (2010). An ANOVA Analysis of the relationships between business students' learning styles and effectiveness of web based instruction. American Journal of Business Education, 3 (3), 89-98.

Kuhn, M. (2009). Learning Style. E. M. Anderman ve L. H. Anderman (Eds.). Pschology of Classroom Learning: An Encyclopedia. USA: Macmillan Social Science Library.

Lipman, M. (1988). Critical thinking: What can it be? Education Leadership, 46 (1), 38-43.

Litch, M. H. (1998). Multiple Regression and Correlation. Laurence G. Grimm ve Paul R. Yarnold (Eds.), Reading and Understanding Multivariate Statistics. Washington, DC: American Psychological Association.

Mahmoud, H. G. (2012). Critical thinking dispositions and learning styles of baccalaureate nursing students and its relation to their achievement. International Journal of Learning ve Development, 2 (1), 398-415.

Marzano, R. J., Pickering, D. J. ve Pollock, J. E. (2001). Classroom Instruction that Works: Research-Based Strategies for Increasing Students Achievement. USA: Association for Supervision and Curriculum Development.

McGlone, J. R. (2011). Adult learning styles and online educational preference. Research in Higher Education Journal, 12, 1-9.

McMillan, J. H. (1987). Enhancing college students critical thinking: A review of studies. Research in Higher Education, 26 (1), 3-29.

Meydan, C. H. ve Şeşen, H. (2010). Yapısal Eşitlik Modeli Uygulamaları. Ankara: Detay Yayıncılık.

Micheal, J. A. ve Modell, H. I. (2003). Active Learning in Secondary and College Science Classrooms: A Working Model for Helping the Learner to Learn. London: Lawrence Erlbaum Associates, Inc.

Myers, B. E., ve Dyer, J. E. (2006). The influence of student learning style on critical thinking skill. Journal of Agricultural Education, 47 (1), 43-52.

Park, S. ve Kwon, I. G. (2007). Factors influencing nurses' clinical decision making--focusing on critical thinking disposition. Taehan Kanho Hakhoe Chi, 37 (6), 863-871.

Paulhus, D. L. (1991). Measurement and Control of Response Bias. J.P. Robinson, P. Shaver, ve L.S. Wrightsman (Eds.), Measures of Personality and Social Psychological Attitudes. San Diego, CA: Academic Press.

Perkins, D. N., Jay, E., ve Tishman, S. (1993). Beyond abilities: A dispositional theory of thinking. MerrillPalmer Quarterly: Journal of Developmental Psychology, 39 (1), 1-21.

Pritchard, A. (2009). Ways of Learning: Learning Theories and Learning Styles in the Classroom. NY: Taylor \& Francis e-Library.

Rafael, G-R ve Francisco, P-G (2011). Assessment preferences of preservice teachers: analysis according to academic level and relationship with learning styles and motivational orientation. Teaching in Higher Education, 16 (6), 719-731. 
Reichman, S. W. ve Grasha, A. F. (1974). Grasha-Reichmann Student Learning Styles Scales. 20.03.2013 tarihinde http://www.angelfire.com/ny3/toddsvballpage/Cognitive/GR.pdf adresinden erişilmiştir.

Reid, G. (2005). Learning Styles and Inclusion. London: Paul Chapman Publishing.

Rogers, P. R. ve McNeill (2009). Student learning styles and online course performance: An empirical examination of student success in web-based management courses. Business Education Digest, 17, 1-15.

Ryan, A. M. (2009). Peer Relationships: Overview. Eric M. Anderman ve Lynley H. Anderman (Eds.), Pschology of Classroom Learning: An Encyclopedia. USA: Macmillan Social Science Library.

Schafersman, S. D. (1991). An Introduction to critical thinking. 11.03.2012 tarihinde

http://smartcollegeplanning. org adresinden erişilmiştir.

Schunk, D. H. (2009). Öğrenme Teorileri: Eğitimsel Bir Bakışla (Muzaffer Şahin, Çev. Ed.). Ankara: Nobel Yayın Dağıtım.

Scott, C. (2010). The enduring appeal of 'learning styles'. Australian Journal of Education, 54 (1), 5-17.

Sims, R. R. ve Sims, S. J. (1995). Learning and Learning Styles: A Review and Look to the Future. Serbrenia J. Sims ve Ronald R. Sims (Eds.). The Importance of Learning Styles: Understanding the Implications for Learning, Course Design, and Education. London: Greenwood Press.

Sinclaire, J. (2012). Vark learning style and student satisfaction with traditional and online courses. International Journal of Education Research, 7 (1), 77-88.

Siegel, H. (1988). Educating Reason: Rationality, Critical Thinking, and Education. New York: Routledge.

Smith, G. F. (2003). Beyond critical thinking and decision making: Teaching business students how to think. Journal of Management Education, 27 (24), 24-51.

Spring, J. (2010). Özgür Eğitim (A. Ekmekçi, Çev.). İstanbul: Ayrıntı Yayınları.

Stanovic, K. E. ve West, R. F. (1997). Reasoning independently of prior belief and individual differences in actively open-minded thinking. Journal of Educational Psychology, 89 (2), 342-357.

Sulaiman, W. S. W., Rahman, W. R. A. ve Dzulkifli, M. A. (2008). Relationship between critical thinking dispositions, perceptions towards teachers, learning approaches and critical thinking skills among university students. The Journal of Behavioral Science, 3 (1), 122-133.

Taylor, G. R. ve Mackenney, L. (2008). Improving Human Learning in the Classroom: Theories and Teaching Practices. USA: Rowman ve Littlefield Education.

Terregrossa, R. A., Englander, F. ve Wang, Z. (2010). How student achievement is related to student behaviors and learning style preferences. International Journal of Education Research, 5 (2), 94-108.

Torres, R. M. ve Cano, J. (1995). Critical thinking as influenced by learning style. Journal of Agricultural Education, 36 (4), 55-62.

Troldahl, V. ve Powell, F. (1965). A short-form dogmatism scale for use in field studies. Social Forces, 44, 211-215.

Tsui, L. (1999). Courses and instruction affecting critical thinking. Research in Higher Education, 40 (2), 185-200.

Tuan, L. T. (2011). Matching and stretching learners' learning styles. Journal of Language Teaching and Research, 2 (2), 285-294.

Tulbure, C. (2012). Investigating the relationships between teaching strategies and learning styles in higher education. Acta Didactica Napocensia, 5 (1), 65-74.

Turkanis, C. G., Barlett, L. ve Rogoff, B. (2001). Never-Ending Learning. B. R. Turkanis, C. G. Turkanis ve L. Bartlett (Eds.). Learning Together: Children and Adults in a School Community. New York: Oxford University Press, Inc.

Zacharis, N. Z. (2010). The impact of learning styles on student achievement in a web based versus an equivalent face to face course. College Student Journal, 44 (3), 591-597.

Zacharis, N. Z. (2011). The effect of learning style on preference for web-based courses and learning outcomes. British Journal of Educational Technology, 42 (5), 790-800.

Zarbaskhsh, M., Hassanzadeh, S., Abolghasemi, S. ve Dinani, P. T. (2012). Relationship between perceived parenting styles and critical thinking with cognitive learning styles. Journal of Basic and Applied Scientific Research, 2 (10), 10007-10011.

Zhang, H. ve Lambert, V. (2008). Critical thinking dispositions and learning styles of baccalaureate nursing students from China. Nursing ve Health Sciences, 10 (3), 175-181.

Zhou, M. (2011). Learning styles and teaching styles in college english teaching. International Education Studies, 4 (1), 73-77. 